\title{
Population genetic structure of Blue Swimming Crab (Portunus pelagicus) in the Gulf of Thailand
}

\author{
VERAKIAT SUPMEE ${ }^{1, \boldsymbol{}}$, AMONSAK SAWUSDEE ${ }^{2}$, PRADIT SANGTHONG $^{3}$, JUTHAMAS SUPPAPAN $^{4}$ \\ ${ }^{1}$ Department of Science, Faculty of Science and Technology, Rajamangala University of Technology Srivijaya. Nakhon Si Thammarat, 80110, Thailand \\ ${ }^{2}$ Division of Technology for Marine and Coastal Resources Management, School of Engineering and Resources Management, Walailak University. \\ Nakhon Si Thammarat 80161, Thailand \\ ${ }^{3}$ Department of Genetics, Faculty of Science, Kasetsart University. Bangkok 10900, Thailand \\ ${ }^{4}$ Science Education Program, Faculty of Education, Nakhon Si Thammarat Rajabhat University. Nakhon Si Thammarat 80280, Thailand \\ Tel./fax.: +66-75-773336, `email: verakiat.s@rmutsv.ac.th
}

Manuscript received: 10 July 2020. Revision accepted: 24 August 2020.

\begin{abstract}
Supmee V, Sawusdee A, Sangthong P, Suppapan J. 2020. Population genetic structure of Blue Swimming Crab (Portunus pelagicus) in the Gulf of Thailand. Biodiversitas 21: 4260-4268. The Blue Swimming Crab (Portunus pelagicus) is an important commercial fishery product in the Gulf of Thailand. To provide a strategy for management, information on genetic features is needed. In our study, the population genetic structure and demographic history of the P. pelagicus living in the Gulf of Thailand were analyzed based on the variation of the nucleotide sequence of the mitochondrial DNA in the control region (mtDNA $C R$ ). Ninety-seven samples were collected from 5 sampling sites: Rayong, Chonburi, Chumphon, Surat Thani, and Nakhon Si Thammarat provinces in the Gulf of Thailand. Fortynine haplotypes were identified and 39 private haplotypes were found. An AMOVA showed no genetic structure among populations. The pairwise $F_{S T}$ also indicated no statistically significant difference between all possible regional combinations. The topology of a minimum spanning network revealed a star-like topology that was not separated by geographic structure. The historical demographic analysis revealed a stable population size for a long period and followed by a very recent expansion. An absence of a population structure of the $P$. pelagicus was possibly caused by a high level of gene flow. The results of this study differ from previous studies that used genetic markers in nuclear DNA. Thus, to clear the genetic structure information of $P$. pelagicus in the Gulf of Thailand, we suggested that more sensitive markers to detect genetic structure should be used in further analysis.
\end{abstract}

Keywords: Blue Swimming Crab, control region, demographic history, genetic diversity, Thailand

\section{INTRODUCTION}

The Blue Swimming Crab (Portunus pelagicus) belongs to the family Portunidae. It is generally found inshore in sandy and muddy habitats as well as among seagrass beds throughout the Indo-West Pacific (Kembaren et al. 2018; Zainal 2013). It is an important commercial seafood product in Thailand (Nitiratsuwan et al. 2013). In 2017, the total catch volume of $P$. pelagicus in Thailand was 28,907 tons. Especially, in the Gulf of Thailand, the important fishing ground was fished about 22,123 tons (Fishery Statistics Analysis and Research Group 2017). Nowadays, numerous commercial product of $P$. pelagicus in the Gulf of Thailand is increasing (Oniam et al. 2018). Further, a large number of the small size of wildcaught crabs are increasing, indicating overexploitation of this species (Anantasuk and Nitiratsuwan 2015).

Population genetic structure is referred to as the pattern of genetic diversity across multiple demes (Reed and Frankham 2003). Genetic diversity is maintained by gene flow and correlated with population fitness (Garner et al. 2005). Then understanding the genetic structure is necessary for the conservation of the organism (Frankham et al. 2002). The population genetic structure of $P$. pelagicus in Thailand was studied by Klinbunga et al. (2010) and Klinbunga et al. (2007), and the result showed a restricted gene flow level of $P$. pelagicus in Thai waters. Many studies have revealed the genetic structure in various marine populations in the Gulf of Thailand such as Donax spp. (Manatrinon et al. 2012), Paphia undulata (Donrung et al. 2011), and Penaeus merguiensis (Wanna et al. 2004). However, the various report revealed that only one population of marine animals in the Gulf of Thailand has been found such as Lates calcarifer (Sodsuk et al. 2012), Rachycentron canadum (Phinchongsakuldit et al. 2013), and Perna viridis (Prakoon et al. 2010). It shows that the population genetic structure of marine species living in the Gulf of Thailand does not occur in all marine species.

The genetic feature of $P$. pelagicus in Thailand was studied using nuclear DNA marker by Klinbunga et al. (2010) (AFLP) and Klinbunga et al. (2007) (RAPD). However, in the past decade, mitochondrial DNA (mtDNA) has been extensively used for studies regarding the population genetic structure of many marine species (Guo et al. 2011; Durand et al. 2013; Taguchi et al. 2015; Lau et al. 2018) because it has a unique feature, e.g. haploidy, maternal inheritance, high copy number, nonrecombination, and rapid mutation rate (Boore, 1999). Especially, the control region (mtDNA $C R$ ) is a high mutation area within the mtDNA molecule (Avise, 1994). The mutation rate in the mtDNA $C R$ is approximately 5-10 times higher than other regions in the mitochondrial 
genome and is approximately 25-100 times higher than nuclear genes (Boore, 1999). It has been used to examine population genetic structure in various marine crabs such as Episesarma versicolor (Supmee et al. 2012a), $P$. trituberculatus (Shan et al. 2018), and Cardisoma guanhumi (Amaral et al. 2015). Thus, mtDNA $C R$ is one good DNA marker for studies of population structure. In our study, we used the mtDNA $C R$ to study the genetic structure of $P$. pelagicus in the Gulf of Thailand as additional information in addition to the nuclear DNA marker such as RAPD and AFLP genetic markers. The objective of the study was to examine the population genetic structure and the demographic history of $P$. pelagicus living in the Gulf of Thailand based on the nucleotide sequence of mtDNA $C R$. This information would assist the management of $P$. pelagicus to aid policy design about fisheries and conservation management.

\section{MATERIALS AND METHODS}

\section{Sampling}

Ninety-seven of $P$. pelagicus were caught from 5 sampling sites: Rayong $(N=17)$, Chonburi $(N=19)$, Chumphon $(N=19)$, Surat Thani $(N=22)$, Nakhon Si Thammarat $(N=20)$ in the Gulf of Thailand (Figure 1). Fresh samples were stored in ice during transportation to a laboratory and kept at $-20{ }^{\circ} \mathrm{C}$ until required.

\section{DNA extraction, PCR amplification, and nucleotide sequencing}

Total genomic DNA was extracted from the muscle in the walking leg using the Genomic DNA Extraction Kit (Tiangen BioTech, China) followed by the manufacturer protocol. Based on the complete nucleotide sequence database in mtDNA $C R$ of $P$. pelagicus from the National Center for Biotechnology Information (accession number: MN635711.1, Koolkarnkhai et al. 2019), primers were designed using Primer 3 program (Untergasser et al. 2012) to amplify the partial nucleotide sequence of the control region. The pair of primers was PPCR_H1 5'-TTG AGG GAA ACC AGA AAG ATT 3' and PPCR_L1 5'-CCA TGC GTT AAA ATA CAA ATT C 3'. The polymerase chain reaction (PCR) was conducted. The reaction mixture, a total volume of $50 \mathrm{ml}$, consisted of 10X Taq buffer $5 \mathrm{ml}$, $25 \mathrm{mM} \mathrm{MgCl}_{2} 7.5 \mathrm{ml}, 2 \mathrm{mM}$ dNTPs mix $4 \mathrm{ml}, 10 \mathrm{mM}$ forward primer $2 \mathrm{ml}, 10 \mathrm{mM}$ reverse primer 2 $\mathrm{ml}$, Taq DNA polymerase (RBCbiosciences, USA) $0.5 \mathrm{ml}$ (2.5 unit), total DNA $5 \mathrm{ml}(50-100 \mathrm{ng})$ and ultrapure water $24 \mathrm{ml}$. The reaction mixtures were amplified in Major Cycler, CYCLER, TAIWAN. The PCR cycling profile consisted of initial denaturation at $94^{\circ} \mathrm{C}$ for $4 \mathrm{~min}$, followed by 35 cycles of $94^{\circ} \mathrm{C}$ for $40 \mathrm{sec}, 52.5^{\circ} \mathrm{C}$ for $1 \mathrm{~min}, 72^{\circ} \mathrm{C}$ for $1 \mathrm{~min}$, and a final extension at $72^{\circ} \mathrm{C}$ for $5 \mathrm{~min}$. The correct size of the PCR products was checked by gel electrophoresis technique. The PCR products were purified by using Gel/PCR Purification Mini Kit (TiangenBioTech, China) according to the manufacturer's protocol. The purified DNA was sent to $1^{\text {ST }}$ Base Laboratory, Malaysia for direct sequencing.

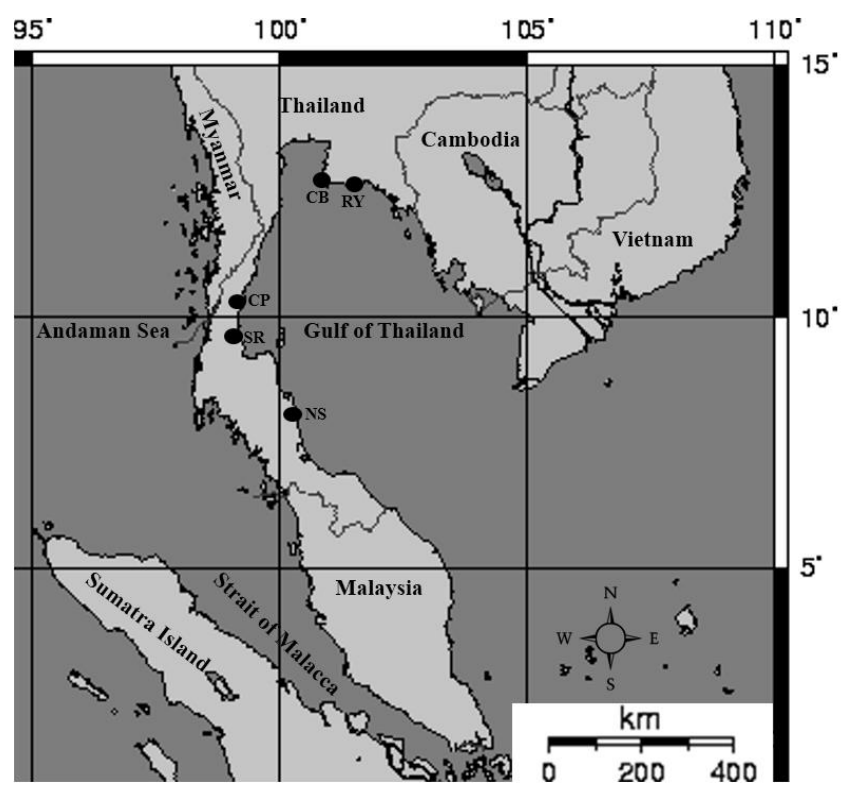

Figure 1. Map showing sampling areas of the Portunus pelagicus from the Gulf of Thailand: the upper Gulf of Thailand; Rayong (RY), and Chonburi (CB): the lower Gulf of Thailand; Chumphon (CP), Surat Thani (SR), and Nakhon Si Thammarat (NS)

\section{Data analysis \\ Genetic diversity}

Sequences obtained from each specimen were initially confirmed with the reference sequence of mtDNA $C R$ from NCBI (accession number: MN635711.1, Koolkarnkhai et al. 2019). Multiple sequences were aligned using ClustalW version 2.0.12 (Larkin et al. 2007) and the ambiguous positions of the aligned sequences were adjusted manually. The genetic diversity analysis including the nucleotide diversity $(\pi)$, haplotype diversity $(h)$, and the number of polymorphic sites among all haplotypes per population and total population were calculated using DnaSP version 6.00 (Rozas et al. 2017).

\section{Population genetic structure}

The population genetic structure of $P$. pelagicus was determined based on 2 putative structures. The samples were separated into a single region according to the sampling sites (RY, CB, CP, SR, and NS) for the first structure. For the second structure, the specimens were determined according to the geographic-based regions: the upper Gulf of Thailand (RY and CB) and the lower Gulf of Thailand (CP, SR, and NS). An analysis of molecular variance (AMOVA) was performed with ARLEQUIN v. 3.5 (Excoffier and Lischer 2010) to compare levels of genetic diversity within and among putative populations. The associated $F$-statistic analogs including $\Phi_{C T}, \Phi_{S C}$, and $\Phi_{S T}$ were estimated at different hierarchical levels using 10,000 permutations. Pairwise $F_{S T}$ was used to estimate the genetic distances between all possible combinations of populations using 10,000 permutations. A minimum spanning network (MSN) was constructed using ARLEQUIN based on the mean number of pairwise differences between all haplotypes of the mtDNA $C R$ and drawn by hand. 


\section{Demographic history}

The demographic history of $P$. pelagicus was examined by using 3 different approaches. Firstly, neutrality tests for each sampling locality and the entire Gulf of Thailand population were tested using Fu's $F s$ (Fu 1997) and Tajima's $D$ (Tajima 1989) statistics based on 10,000 replicates. Secondly, the mismatch distribution analysis under the sudden expansion model was estimated as implemented in ARLEQUIN. The fit between observed and expected mismatch distribution was tested using the Harpending raggedness index (Harpending 1994). The sum of squared deviations ( $S S D$ ) was performed to test the goodness-of-fit with 10,000 bootstrap replicates. Finally, Bayesian skyline analysis was calculated by using BEAST/BEAUTi ver. 1.7.2 (Drummond et al. 2012) to infer the temporal change in the effective population size $(\mathrm{Ne})$. Due to a lack of the evolutionary rate of the mtDNA $C R$ in crabs, we employed a mutation rate of $19 \%$ per million years, as used by Farfantepenaeus aztecus (McMillen-Jackson and Bert 2003). The Bayesian skyline plot was generated by Tracer ver. 1.6 (Rambaut et al. 2014).

\section{RESULTS AND DISCUSSION}

\section{Genetic diversity}

Partial nucleotide sequences of mtDNA $C R$ from 97 individuals of $P$. pelagicus were $411-417$ base pairs. The average nucleotide compositions of $\mathrm{A}, \mathrm{T}, \mathrm{G}$, and $\mathrm{C}$ were $41.3 \%, 34.0 \%, 8.3 \%$, and $16.4 \%$, respectively. The A+T base content was $75.3 \%$ and $\mathrm{G}+\mathrm{C}$ was $24.7 \%$. The results showed 59 polymorphic sites (36 singleton sites and 23 parsimony informative sites). In total, 49 haplotypes were identified. Nine haplotypes were shared among the sampling localities (H01, H02, H05, H06, H08, H12, H14, H16, and H19), and 1 haplotype was shared within the population (H21). Five populations had their specific characteristic haplotypes (private haplotype). Thirty-nine private haplotypes were found. $\mathrm{CP}$ and SR population possessed 9 private haplotypes, while RY, CB, and NS population carried 7 private haplotypes, respectively (Table 2). Haplotype diversity and nucleotide diversity ranged from 0.868 to 0.985 and 0.009 to 0.011 , respectively. Overall, haplotype diversity and nucleotide diversity were 0.933 and 0.008 , respectively (Table 1 ).

\section{Population genetic structure}

The AMOVA of the first putative structure was not statistically significant $\left(\Phi_{S T}=-0.018, p=0.920\right)$. Regarding the second structure tested (upper Gulf of Thailand x lower Gulf of Thailand), we found no significant genetic structure as well $\left(\Phi_{C T}=-0.002, p=0.799\right)$ (Table 3). Every pairwise $F_{S T}$ of the geographic-based populations showed no significant differences for most pairwise comparisons (Table 4). The haplotype network showed a star-like network and did not indicate any distinct pattern of phylogeographic structure (Figure 2).

\section{Demographic history}

Neutrality tests, the Fu's $F s$, and Tajima's $D$ were performed for each locality and pooled populations (Table 5). Fu's Fs statistics of all populations were statistically significantly negative. The Fs statistic of the pooled population showed a statistically significant negative value (Fs=-26.121, $\quad p=0.000)$. Tajima's $D$ statistics of populations of $\mathrm{CP}$ and NS populations were statistically non-significantly negative, and populations of RY, CB, and SR populations were statistically significantly negative. However, when all populations were pooled together, the $D$ statistic was statistically significant ( $D=-$ 2.221, $p=0.000)$. According to the measured SSD from the goodness-of-fit test, the mismatch distribution observed from the pooled population did not fit a sudden expansion model ( $S S D=0.122, p=0.002)$. The Harpending raggedness indices revealed non-significant low values $(r g=0.032, p=0.924)$ (Table 5). Mismatch distribution determined from the total sample was bimodal (Figure 3). The Bayesian skyline analysis revealed that the expansion time of the $P$. pelagicus population in the Gulf of Thailand had occurred around 3,000 years ago (Figure 4).

Table 1. Collecting localities, number of individuals per sampling site $(N)$, number of polymorphic sites, number of haplotypes, haplotype diversity $(h)$, and nucleotide diversity $(\pi)$ of Portunus pelagicus living along the Gulf of Thailand coast

\begin{tabular}{|c|c|c|c|c|c|}
\hline Collecting localities & $N$ & $\begin{array}{c}\text { No. } \\
\text { polymorphic sites }\end{array}$ & $\begin{array}{c}\text { No. } \\
\text { haplotypes }\end{array}$ & $\begin{array}{c}\text { Haplotype diversity }(h) \\
(\text { mean } \pm \text { SD) }\end{array}$ & $\begin{array}{c}\text { Nucleotide diversity }(\pi) \\
(\text { mean } \pm \text { SD) }\end{array}$ \\
\hline Rayong (RY) & 17 & 26 & 15 & $0.985 \pm 0.025$ & $0.010 \pm 0.002$ \\
\hline Chonburi (CB) & 19 & 26 & 13 & $0.930 \pm 0.047$ & $0.011 \pm 0.002$ \\
\hline Chumphon (CP) & 19 & 24 & 16 & $0.982 \pm 0.022$ & $0.011 \pm 0.001$ \\
\hline Surat Thani (SR) & 22 & 27 & 15 & $0.939 \pm 0.037$ & $0.009 \pm 0.001$ \\
\hline Nakhon Si Thammarat (NS) & 20 & 22 & 11 & $0.868 \pm 0.057$ & $0.009 \pm 0.002$ \\
\hline Total & 97 & 59 & 49 & $0.933 \pm 0.016$ & $0.008 \pm 0.000$ \\
\hline
\end{tabular}


Table 2. Haplotype distributions of Portunus pelagicus from 5 localities in the Gulf of Thailand

\begin{tabular}{|c|c|c|c|c|c|c|c|c|c|c|c|c|c|}
\hline Haplotype & RY & CB & $\mathbf{C P}$ & SR & NS & Total & Haplotype & RY & CB & $\mathbf{C P}$ & SR & NS & Total \\
\hline H01 & 1 & - & 1 & - & - & 2 & H26 & - & - & 1 & - & - & 1 \\
\hline $\mathrm{H} 02$ & 2 & 5 & 2 & 2 & 6 & 17 & $\mathrm{H} 27$ & - & - & 1 & - & - & 1 \\
\hline $\mathrm{H} 03$ & 1 & - & - & - & - & 1 & $\mathrm{H} 28$ & - & - & 1 & - & - & 1 \\
\hline $\mathrm{H} 04$ & 1 & - & - & - & - & 1 & $\mathrm{H} 29$ & - & - & 1 & - & - & 1 \\
\hline $\mathrm{H} 05$ & 1 & - & 1 & - & - & 2 & $\mathrm{H} 30$ & - & - & 1 & - & - & 1 \\
\hline H06 & 1 & - & 1 & 1 & - & 3 & H31 & - & - & 1 & - & - & 1 \\
\hline H07 & 1 & - & - & - & - & 1 & H32 & - & - & 1 & - & - & 1 \\
\hline H08 & 3 & 1 & 2 & 6 & 5 & 17 & H33 & - & - & 1 & - & - & 1 \\
\hline H09 & 1 & - & - & - & - & 1 & H34 & - & - & - & 1 & - & 1 \\
\hline $\mathrm{H} 10$ & 1 & - & - & - & - & 1 & $\mathrm{H} 35$ & - & - & - & 1 & - & 1 \\
\hline $\mathrm{H} 11$ & 1 & - & - & - & - & 1 & H36 & - & - & - & 1 & - & 1 \\
\hline H12 & 1 & 1 & - & - & - & 2 & H37 & - & - & - & 1 & - & 1 \\
\hline $\mathrm{H} 13$ & 1 & - & - & - & - & 1 & H38 & - & - & - & 1 & - & 1 \\
\hline H14 & 1 & - & 1 & - & - & 2 & H39 & - & - & - & 1 & - & 1 \\
\hline H15 & - & 1 & - & - & - & 1 & $\mathrm{H} 40$ & - & - & - & 1 & - & 1 \\
\hline H16 & - & 1 & - & 1 & 1 & 3 & H41 & - & - & - & 1 & - & 1 \\
\hline $\mathrm{H} 17$ & - & 1 & - & - & - & 1 & $\mathrm{H} 42$ & - & - & - & 1 & - & 1 \\
\hline H18 & - & 1 & - & - & - & 1 & $\mathrm{H} 43$ & - & - & - & 1 & 1 & 1 \\
\hline H19 & - & 2 & 2 & 3 & 1 & 8 & $\mathrm{H} 44$ & - & - & - & - & 1 & 1 \\
\hline $\mathrm{H} 20$ & - & 1 & - & - & - & 1 & H45 & - & - & - & - & 1 & 1 \\
\hline $\mathrm{H} 21$ & - & 2 & - & - & - & 2 & H46 & - & - & - & - & 1 & 1 \\
\hline $\mathrm{H} 22$ & - & 1 & - & - & - & 1 & $\mathrm{H} 47$ & - & - & - & - & 1 & 1 \\
\hline $\mathrm{H} 23$ & - & 1 & - & - & - & 1 & $\mathrm{H} 48$ & - & - & - & - & 1 & 1 \\
\hline $\mathrm{H} 24$ & - & 1 & - & - & - & 1 & H49 & - & - & - & - & 1 & 1 \\
\hline $\mathrm{H} 25$ & - & - & 1 & - & - & 1 & Total & 17 & 19 & 19 & 22 & 20 & 97 \\
\hline
\end{tabular}

Note: Stations codes are given in Table 1.

Table 3. A hierarchical analysis of molecular variance (AMOVA) based on nucleotide sequence in mtDNA CR of Portunus pelagicus

\begin{tabular}{|c|c|c|c|c|c|}
\hline Source of variation & df & $\begin{array}{c}\text { Sum of } \\
\text { squares }\end{array}$ & $\begin{array}{c}\text { Variance } \\
\text { components }\end{array}$ & $\begin{array}{c}\text { Percentage of } \\
\text { variation }\end{array}$ & $p$-value \\
\hline \multicolumn{6}{|l|}{ Single region } \\
\hline Among populations & 4 & 4.734 & $-0.032 \mathrm{Va}$ & -1.81 & $\Phi_{S T}=-0.018,(p=0.920)$ \\
\hline Within populations & 92 & 166.050 & $1.804 \mathrm{Vb}$ & 101.81 & \\
\hline Total & 96 & 170.784 & & & \\
\hline \multicolumn{6}{|l|}{ Upper and lower of Gulf of Thailand } \\
\hline Among groups & 1 & 1.041 & $-0.004 \mathrm{Va}$ & -0.26 & $\Phi_{C T}=-0.002,(p=0.799)$ \\
\hline Among populations within groups & 3 & 3.693 & $-0.029 \mathrm{Vb}$ & -1.66 & $\Phi_{S C}=-0.016,(p=0.845)$ \\
\hline Within populations & 92 & 166.050 & $1.804 \mathrm{Vc}$ & 101.92 & $\Phi_{S T}=-0.019,(p=0.923)$ \\
\hline Total & 96 & 170.784 & 1.770 & & \\
\hline
\end{tabular}

Note: $p$ values in parentheses

Table 4. Population pairwise $F_{S T}$ values based on nucleotide sequence in mtDNA CR of Portunus pelagicus

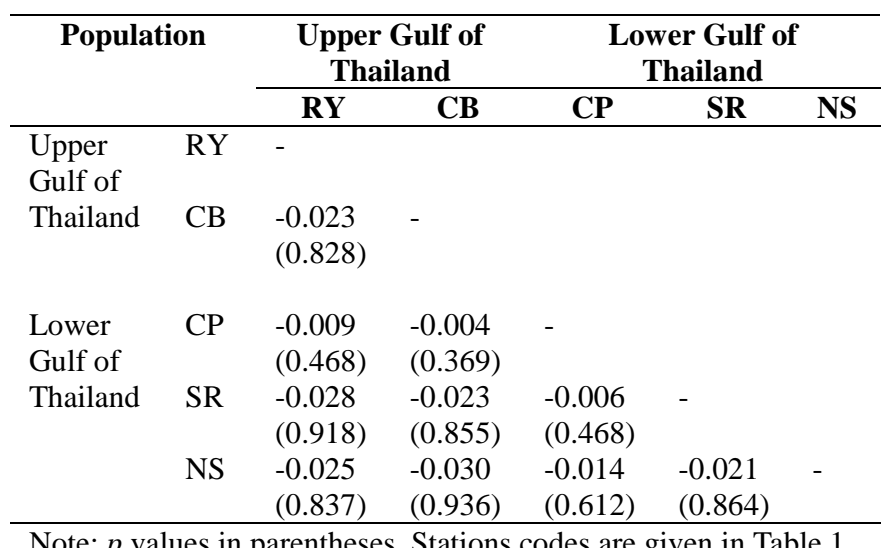

Table 5. Neutrality test and parameter indices of mismatch distribution analysis based on nucleotide sequence in mtDNA $C R$ of Portunus pelagicus

\begin{tabular}{lcccc}
\hline $\begin{array}{l}\text { Collecting } \\
\text { localities }\end{array}$ & Fu's $\mathbf{F s}$ & $\begin{array}{c}\text { Tajima's } \\
\boldsymbol{D}\end{array}$ & $\begin{array}{c}\text { Sum of } \\
\text { squared } \\
\text { deviations } \\
(\boldsymbol{S S D})\end{array}$ & $\begin{array}{c}\text { Raggedness } \\
\text { index } \\
(\boldsymbol{r g})\end{array}$ \\
\hline Rayong & $-9.601 *$ & $-1.924^{*}$ & 0.033 & 0.089 \\
Chonburi & $(0.000)$ & $(0.014)$ & $(0.092)$ & $(0.190)$ \\
& $-6.085^{*}$ & $-1.687 *$ & 0.065 & 0.065 \\
Chumphon & $(0.001)$ & $(0.029)$ & $(0.059)$ & $(0.404)$ \\
& $-10.141^{*}$ & -1.270 & 0.050 & 0.049 \\
Surat Thani & $-6.382^{*}$ & $-1.735 *$ & 0.129 & $(0.384)$ \\
Nakhon Si & $(0.002)$ & $(0.023)$ & $(0.059)$ & $(0.980)$ \\
Thammarat & $-3.670 *$ & -1.432 & 0.029 & 0.057 \\
Total & $(0.027)$ & $(0.060)$ & $(0.752)$ & $(0.693)$ \\
& $-26.121^{*}$ & $-2.221 *$ & 0.122 & 0.032 \\
& $(0.000)$ & $(0.000)$ & $(0.002)$ & $(0.924)$ \\
\hline
\end{tabular}




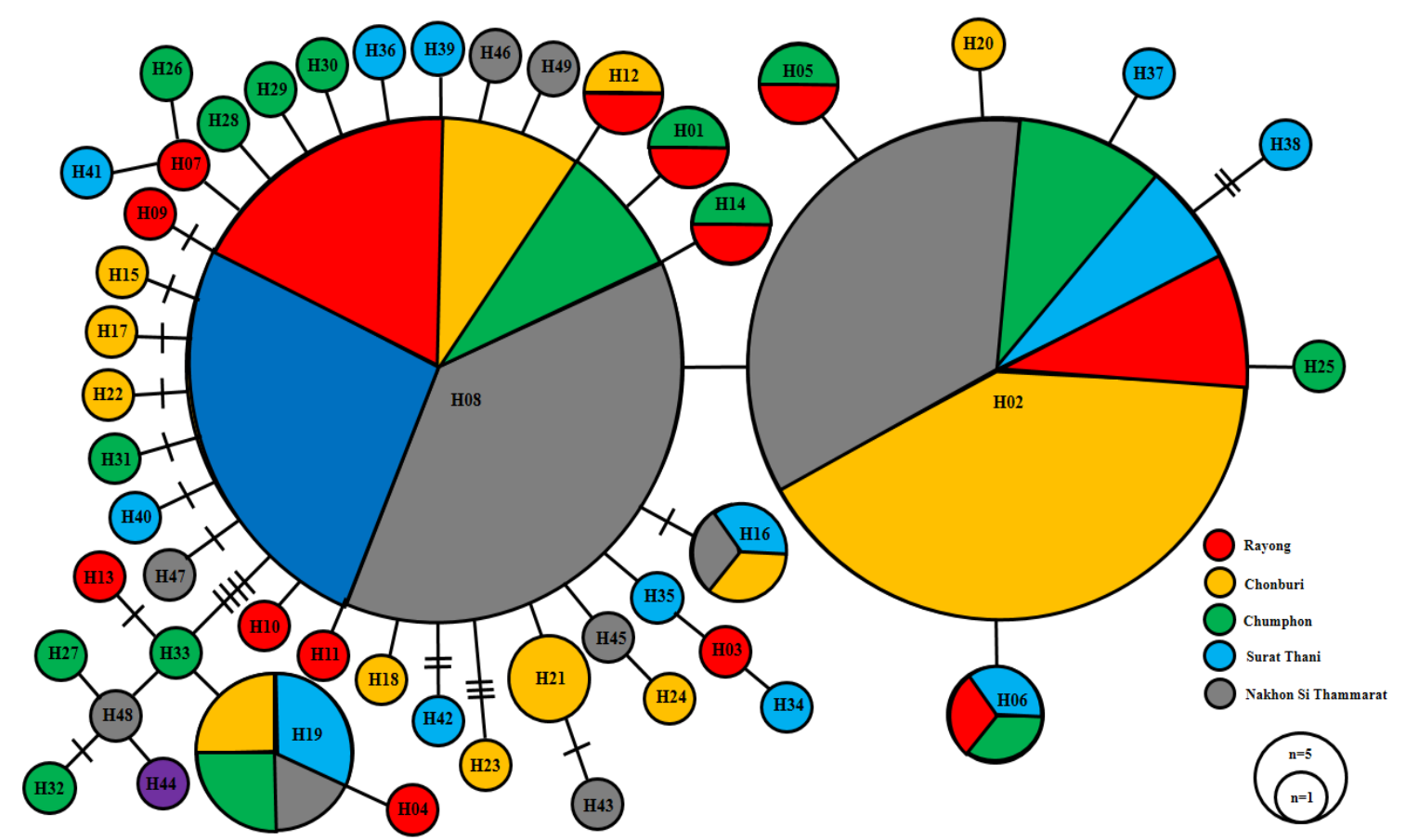

Figure 2. Minimum spanning network of mtDNA $C R$ haplotypes of the Portunus pelagicus: Circles represent haplotypes and their size is proportional to the observed frequency. The color in the circle is the collecting site. The single line connecting directly between haplotype is one mutation step. The number of vertical bars on the connecting line is an increasing number of mutation steps

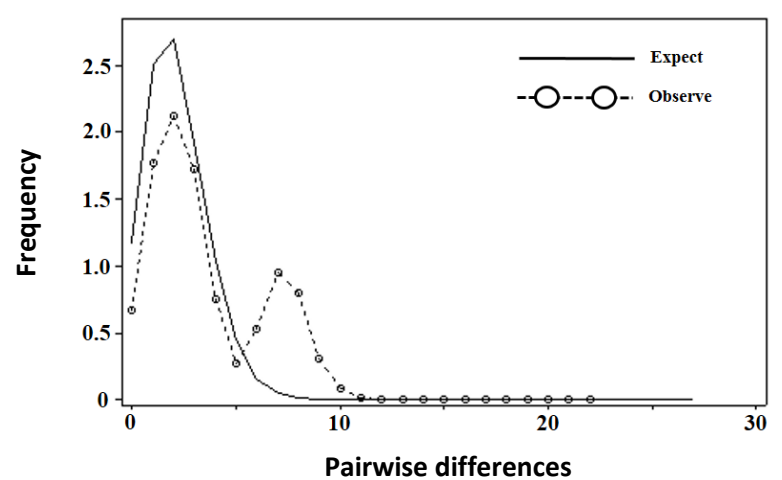

Figure 3. Mismatch distribution under a sudden population expansion model based on nucleotide sequence in mtDNA $C R$ of Portunus pelagicus

\section{Discussion}

Genetic diversity

In our study, it was found that $\mathrm{A}+\mathrm{T}$ base content is higher than $\mathrm{G}+\mathrm{C}$ base content, which is consistent with other reports that $\mathrm{A}+\mathrm{T}$ base content is higher in the mitochondrial genome in animals (Fourdrilis et al. 2018). A total of 49 mtDNA CR haplotypes were analyzed and 39 haplotypes were private. The presence of many private haplotypes in all populations included in our study indicated the existence of a large female effective population size of the P. pelagicus in the Gulf of Thailand (Lewontin 1974). This haplotype frequency is thought to reflect a large effective population size that allowed for the

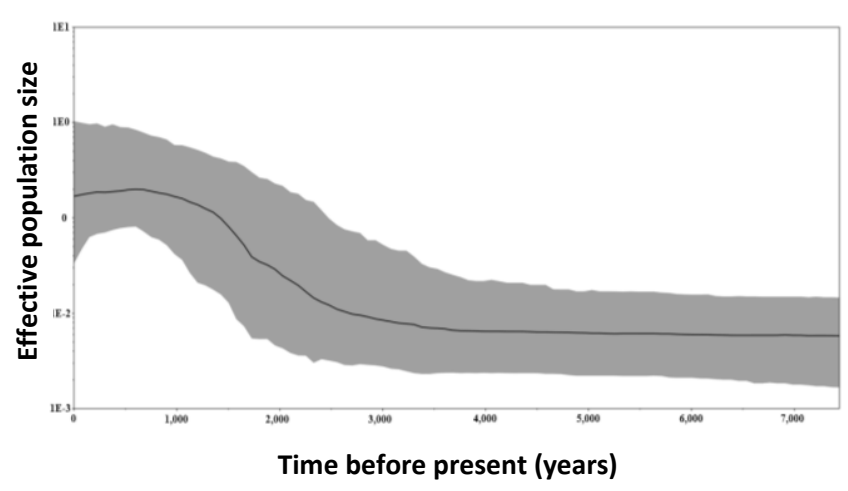

Figure 4. Bayesian skyline plots showing the historical demography of Portunus pelagicus in the Gulf of Thailand. The black line is the median estimation and the highlight is the limit of $95 \%$ confidence interval

retention of numerous unique haplotypes in the female. The nucleotide diversity of the $P$. pelagicus in our study was 0.008. Comparing with those of other crabs, the nucleotide diversity in the mtDNA $C R$ of the P. pelagicus in the Gulf of Thailand was low. For example, the nucleotide diversity of the P. trituberculatus was 0.020 (Guo et al. 2011) and 0.025 (Hui et al. 2019), C. guanhumi was 0.027 (Amaral et al. 2015), and E. mederi was 0.023 (Supmee et al. 2012b). A high value of haplotype diversity but a low level of nucleotide diversity was presented within the $P$. pelagicus population in the Gulf of Thailand. This genetic variation pattern has been revealed in various crustacean species, such as Fennneropenaeus chinensis (Kong et al. 2010), E. 
versicolor (Supmee et al. 2012a), and Varuna litterata (Suppapan et al. 2017).

Population genetic structure

The main factor to generate the genetic structure of marine animals in the Gulf of Thailand was the water circulation, the long-distance between habitat, and the reproductive behavior of marine species. Firstly, in the Gulf of Thailand, the seasonal currents showed a counterclockwise gyre in the upper gulf and clockwise gyre in the lower gulf during the southwest monsoon season. In the northeast monsoon season, the sea currents showed a clockwise gyre in the upper gulf and counterclockwise gyre in the lower gulf. (Sojisuporn et al. 2010). In the central gulf, the sea current revealed a clockwise gyre connected with the sea current of the lower and upper gulf in all monsoon season (Saramul 2017). The different flow patterns of sea current in the Gulf of Thailand act like geographic obstacles and prevent the gene flow between populations (Panithanarak 2017). The results of a study of population genetics using different genetic markers of marine animals in the Gulf of Thailand found that the genetic structure was caused by water circulation such as $P$. pelagicus (RAPD) (Klinbunga et al. 2010), Donax spp. (ISSR) (Manatrinon et al. 2012), and P. monodon (mtDNA COI) (Khamnamtong et al. 2009). Secondly, the long distance between the upper and lower Gulf of Thailand population causes the exchange of genes to be restricted during the planktonic larva. Donrung et al. (2011) examined the genetic structure of $P$. undulata in the Gulf of Thailand by using the ISSR technique as a genetic marker. The result revealed that the distance of $450 \mathrm{~km}$ between the upper and lower Gulf of Thailand prevented the gene flow of this species. Thirdly, the reproductive behavior of marine species affects the genetic structure. For example, the reproductive process of a mature female of $P$. pelagicus is migrated outward to the deep sea for spawning and returns to the original habitation after spawning (Hamid et al. 2016). This reproductive behavior was limited habitats of the $P$. Pelagicus and a population genetic structure was formed.

This finding of the present study revealed that most of the population genetic structure analysis showed a lack of population genetic structure of $P$. pelagicus in the Gulf of Thailand. These results suggested a high-level gene flow of $P$. pelagicus in the Gulf of Thailand. The low levels of genetic differentiation among the $P$. pelagicus populations were reported in many areas such as $P$. pelagicus population living along with the coastal areas of Malaysia that inferred from microsatellites marker (Chai et al. 2017) and $P$. pelagicus population living along the southeastern area of China that analyzed based on mtDNA COI sequences (Ren et al. 2018). Genetic homogeneity of the $P$. pelagicus population in the Gulf of Thailand was plausibly maintained by the long duration of the planktonic larva stage. $P$. pelagicus had a long larval phase at the age of 2645 days and high dispersal ability (Efrizal 2016). Most marine species spend part of the stage of their life cycle in the open sea as free-moving gametes, larvae, or adults (Uthicke and Benzie, 2003). Especially, marine species with a long duration of the larval stages are believed to have high levels of genetic variation within populations (Russo et al. 1994). Additionally, a long-duration planktonic larval stage influences the opportunity for a high degree of gene flow as evidenced by an absence of genetic differentiation in several species, for example, Neritina canalis and Neripteron dilatatus (46 days) (Crandall et al. 2010), Neosarmatium meinerti (43 days) (Huang et al. 2018), and Uca annulipes (28 days) (Silva et al. 2010). Further, the long larva duration may enhance the mixing of the planktonic larva by the connection of the water circulation among the lower, central, and upper Gulf of Thailand. Thus, it made it possible to promote gene flow that extensively covered these 2 areas. Besides, a lack of geographic barriers in the Gulf of Thailand may not disrupt the gene flow of the $P$. pelagicus population between the upper and the lower Gulf of Thailand. Genetic homogeneity between populations from long-distance marine crabs was maintained by the high ability of larva dispersal. For example, Silva et al. (2010) examined the population structure of $U$. annulipes on the African east coast by using mtDNA $C O I$ as a genetic marker. The result revealed that $U$. Annulipes maintained a high level of gene flow along 3,000 km of the African east coast. Several reports of the different genetic marker technique revealed that only one population of marine animals in the Gulf of Thailand has been found such as $L$. calcarifer (microsatellites) (Sodsuk et al. 2012), Hippocampus kuda (mtDNA CR) (Panithanarak et al. 2010), and Meretrix meretrix (mtDNA COI) (Supmee et al. 2020).

In our result, the genetic structure of $P$. pelagicus in the Gulf of Thailand was different from the findings of Klinbunga et al. (2010) and Klinbunga et al. (2007) that revealed a restricted gene flow level of $P$. pelagicus between geographic samples in the Gulf of Thailand. Different results of the study were likely due to the use of different genetic markers. The studies were done by Klinbunga et al. (2010) and Klinbunga et al. (2007) used the genetic marker in the nuclear genome including RAPD and AFLP techniques to detect genetic structure, while our study employed the mitochondrial genome. In general, nuclear DNA markers have a high level of polymorphism and are powerful DNA markers for quantifying genetic variations within and between populations (Abdul-Muneer 2014). However, comparing the genetic markers between nuclear DNA and the mtDNA in the previous study, it was found that there were different results in each marine species. For example, the Synechogobius ommaturus population living along the coast of China showed a genetic structure by using the mtDNA $C R$ marker (Song et al. 2010a) but revealed a weak genetic structure by using the AFLP marker (Song et al. 2010b). The genetic structure of Haliotis asinine in the Thailand coast was found by using an AFLP genetic marker (Praipue et al. 2010), while a lack of genetic structure was reported based on restriction analysis of mtDNA in $16 S$ rRNA (Klinbunga et al. 2003). Genetic differentiation of the $P$. trituberculatus population along the coast of China was revealed by using a microsatellite marker (Guo et al. 2013), but a weak genetic structure was found by using the mtDNA $C R$ marker $(\mathrm{Wu}$ et al. 2009). Therefore, in the study of the population 
genetic structure of marine animals, various genetic markers should be used for the combined analysis as the results of this study differ from those of previous studies. To clear the genetic structure information of $P$. pelagicus in the Gulf of Thailand, we suggested that more sensitive nuclear DNA markers to detect genetic structure should be used in further analysis.

\section{Demographic history}

A goodness-of fit-test was not fitted with a mismatch distribution under a sudden expansion model. That the observed mismatch distribution was bimodal indicated a stable population size for a long time (Rogers and Harpending 1992). However, the minimum spanning network showed a star-like topology with a lot of single mutation steps. This topology can be found in populations that have sudden expansion (Ferreri et al. 2011). Also, the Bayesian skyline plot showed a recent population expansion. Besides, neutrality test, Fu's Fs, and Tajima's $D$ showed significantly negative deviation from the neutral state and indicated that a recent population expansion of $P$. pelagicus living in the Gulf of Thailand might have occurred (Omori and $\mathrm{Wu}$ 2017). Thus, all independent analyses of the demographic history test revealed that the demographic history of $P$. pelagicus in the Gulf of Thailand was a stable population size for a long period followed by the occurrence of its recent expansion.

In conclusion, this finding of the present study found that the $P$. pelagicus population in the Gulf Thailand was the single population. The low level of the genetic structure of $P$. pelagicus might be caused by a high level of gene flow from a lack of geographic barrier, a long larva duration stage, and high dispersion ability of $P$. pelagicus. However, our findings differ from those of Klinbunga et al. (2010) and Klinbunga et al. (2007) due to the use of different genetic markers. Therefore, for effective management of the genetic diversity of $P$. pelagicus in the Gulf of Thailand, additional studies should be performed using more highly sensitive genetic markers. Population history results show that the population of $P$. pelagicus in the Gulf of Thailand has been stable for a long time and has recently started to rapidly expand the population size.

\section{ACKNOWLEDGEMENTS}

This study was fully granted by the Agricultural Research Development Agency (Public Organization), Thailand: Thailand Blue Swimming Crab Fishery Improvement Project. We would like to thank anonymous reviewers for their valuable suggestions on the manuscript.

\section{REFERENCES}

Abdul-Muneer PM. 2014. Application of Microsatellite Markers in Conservation Genetics and Fisheries Management: Recent Advances in Population Structure Analysis and Conservation Strategies. Genet Res Intl. DOI: 10.1155/2014/691759, Article ID 691759.

Amaral MRX, Albrecht M, McKinley AS, de Carvalho AMF, de Sousa JSC, Diniz FM. 2015. Mitochondrial DNA variation reveals a sharp genetic break within the distribution of the blue land crab Cardisoma guanhumi in the Western Central Atlantic. Molecules 20: 1515815174.

Anantasuk R, Nitiratsuwan T. 2015. Guidelines for Blue Swimming Crab (Portunus pelagicus, Linnaeus, 1758) stock enhancement of a fishery community in Trang province, Andaman Sea coast of Thailand. Fish Res Bull Kasetsart Univ 39 (2): 10-21.

Avise, J.C. 1994. Molecular Markers, Natural History and Evolution. Chapman and Hall, New York.

Boore JL. 1999. Survey and summary animal mitochondria genome. Nucleic Acids Res 27 (8): 1767-1780.

Chai CJ, Esa YB, Ismail MFS, Kamarudin MS. 2017. Population structure of the blue swimmer crab Portunus pelagicus in coastal areas of Malaysia inferred from microsatellites. Zool Stud 56: 26, DOI: 10.6620/ZS.2017.56-26

Crandall ED, Taffel JR, Barber PH. 2010. High gene flow due to pelagic larval dispersal among South Pacific archipelagos in two amphidromous gastropods (Neritomorpha: Neritidae). Heredity 104: 563-572.

Donrung P, Tunkijjanukij S, Jarayabh P, Poompuang S. 2011. Spatial genetic structure of the Surf Clam Paphia undulata in Thailand waters. Zool Stud 50 (2): 211-219.

Drummond AJ, Suchard MA, Xie D, Rambaut A. 2012. Bayesian phylogenetics with BEAUTi and the BEAST 1.7. Mol Biol Evol 29: 1969-1973.

Durand JD, Blel H, Shen KN, Koutrakis ET, Guinand B. 2013. Population genetic structure of Mugil cephalus in the Mediterranean and Black Seas: a single mitochondrial clade and many nuclear barriers. Mar Ecol Prog Ser. 474: 243-261.

Efrizal E. 2016. Effects of temperature on survival rate and larval development of Blue Swimming Crab, Portunus pelagicus (Linnaeus, 1758) under laboratory conditions. Asian J Appl Sci 4 (1): 120-134.

Excoffier L, Lischer HEL. 2010. Arlequin suite ver 3.5: a new series of programs to perform population genetics analysis under Linux and Windows. Mol Ecol Resour 10: 564-567.

Ferreri M, Qu W, Han B. 2011. Phylogenetic networks: A tool to display character conflict and demographic history. Afr J Biotechnol 10 (60): 12799-12803.

Fishery Statistics Analysis and Research Group. 2017. Fisheries Statistics of Thailand, No. 5/2017. Department of Fisheries. Ministry of Agriculture and Cooperatives, Thailand. [Thai]

Fourdrilis S, de Frias Martins AM, Backeljau T. 2018. Relation between mitochondrial DNA hyperdiversity, mutation rate and mitochondrial genome evolution in Melarhaphe neritoides (Gastropoda: Littorinidae) and other Caenogastropoda. Sci Rep 8: 17964. https: //doi.org/10.1038/s41598-018-36428-7.

Frankham R, Briscoe DA, Ballou JD. 2002. Introduction to conservation genetics. Cambridge University Press, New York.

Fu FX. 1997. Statistical tests of neutrality of mutations against population growth, hitchhiking and background selection. Genetics 147: 915925.

Garner A, Rachlow JL, Hicks JF. 2005. Patterns of genetic diversity and its loss in mammalian populations. Conserv Biol 19: 1215-1221.

Guo E, Li X, Liu Y, Cheng Y, Wu CX. 2011. Genetic variation and population structure of swimming crab (Portunus trituberculatus) inferred from mitochondrial control region. Mol Biol Rep. DOI: 10.1007/s11033-011-0882-3.

Guo E, Cui Z, Wu D, Hui M, Liu Y, Wang, H. 2013. Genetic structure and diversity of Portunus trituberculatus in Chinese population revealed by microsatellite markers. Biochem Syst Ecol 50: 313-321.

Hamid A, Lumban Batu DTF, Riani E, Wardiatno Y. 2016. Reproductive biology of Blue Swimming Crab (Portunus pelagicus Linnaeus, 1758) in Lasongko Bay, Southeast Sulawesi-Indonesia. Aquac Aquar Conserv Legis 9 (5): 1053-1066.

Harpending HC. 1994. Signature of ancient population growth in a lowresolution mitochondrial DNA mismatch distribution. Hum Biol 66: 591-600.

Hellberg ME. 2009. Gene flow and Isolation among populations of marine animals. Annu Rev Ecol Evol Syst 40: 291-310.

Huang WC, Chang JT, Liao C, Tawa A, lizuka Y, Liao TY, Shiao JC. 2018. Pelagic larval duration, growth rate, and population genetic structure of the tidepool snake moray Uropterygius micropterus around the southern Ryukyu Islands, Taiwan, and the central Philippines. PeerJ 6: e4741; DOI 10.7717/peerj.4741.

Wu HX, Xu XN, Xue JZ, Dong SL. 2009. Analysis of the genetic structure and relationship of the swimming crab, Portunus 
trituberculatus in the coastal area of China. J Mar Sci 27 (2): 200207.

Hui M, Shi G, Sha Z, Liu Y, Cu Z. 2019. Genetic population structure in the swimming crab, Portunus trituberculatus and its implications for fishery management. J Mar Biol Assoc UK 99 (4): 891-899.

Kembaren DD, Zairion Z, Kamal MM, Wardiatno Y. 2018. Abundance and spatial distribution of Blue Swimming Crab (Portunus pelagicus) larvae during east monsoon in the East Lampung waters, Indonesia. Biodiversitas 19 (4): 1326-1333.

Khamnamtong B, Klinbunga S, Menasveta P. 2009. Genetic diversity and geographic differentiation of the giant tiger shrimp (Penaeus monodon) in Thailand analyzed by mitochondrial COI sequences. Biochem Genet 47: 42-55.

Klinbunga S, Khetpu K, Khamnamtong B, Menasveta P. 2007. Genetic heterogeneity of the Blue Swimming Crab (Portunus pelagicus) in Thailand determined by AFLP analysis. Biochem Genet 45: 725-736.

Klinbunga S, Pripue P, Khamnamtong N, Puanglarp N, Tassanakajon A, Jarayabhand P, Hirono I, Aoki T, Menasveta P. 2003. Genetic diversity and molecular markers of the tropical abalone (Haliotis asinina) in Thailand. Mar Biotechnol 5: 505-517.

Klinbunga S, Yuvanatemiya V, Wongphayak S, Khetpu K, Menasveta P, Khamnamtong B. 2010. Genetic population differentiation of the Blue Swimming Crab Portunus pelagicus (Portunidae) in Thai waters revealed by RAPD analysis. Genet Mol Res 9 (3): 1615-1624.

Kong XY, Li YL, Kong WSJ. 2010. Genetic variation and evolutionary demography of Fenneropenaeus chinensis populations, as revealed by the analysis of mitochondrial control region sequences. Genet Mol Biol 33 (2): 379-389.

Kong, XY, Li YL, Kong WSJ. 2010. Genetic variation and evolutionary demography of Fenneropenaeus chinensis populations, as revealed by the analysis of mitochondrial control region sequences. Genet Mol 33 (2): 379-389.

Koolkarnkhai P, Intakham C, Sangthong P, Surat W, Wonnapinij P. 2019. Portunus pelagicus mtDNA heteroplasmy inheritance and its effect on the use of mtCR and mtCOI sequence data. Mitochondrial DNA A DNA Mapp Seq Anal 30 (8): 848-860.

Larkin MA, Blackshields G, Brown NP, Chenna R, McGettigan PA, McWilliam H, Valentin F, Wallace IM, Wilm A, Lopez R, Thompson JD, Gibson TJ, Higgins DG. 2007. Clustal W and Clustal X version 2.0. Bioinformatics 23 (21): 2947-2948.

Lau JS, Ransangan J, Rodrigues KF .2018. Genetic diversity and population structure of the Asian Green Mussel (Perna viridis) in the waters of Sabah, Malaysia based on mitochondrial DNA D-Loop sequences. Turkish J Fish Aquat Sci 18 (1): 109-117.

Lewontin RC. 1974. The genetic basis of evolutionary change. Columbia University Press, New York.

McMillen-Jackson A, Bert TM. 2003. Disparate patterns of population genetic structure and population history in two sympatric penaeid shrimp species (Farfantepenaeus aztecus and Litopenaeus setiferus) in the eastern United States. Mol Ecol 12: 2895-2905.

Manatrinon S, Thonglor OU, Boonyapakdee A. 2012. Genetic and morphological variation in three populations of Donax spp. in the Gulf of Thailand. Thai J Genet 5 (1): 79-88.

Nitiratsuwan T, Tanyaros S, Panwanitdumrong K. 2013. Distribution of berried female blue swimmer crabs (Portunus pelagicus Linneaus, 1758) in the coastal waters of Trang province, southern Thailand. Maejo Intl J Sci Technol 7 (Special Issue): 52-59.

Omori R, Wu J. 2017. Tajima's D and site specific nucleotide frequency in a population during an infectious disease outbreak. Siam J Appl Math 77 (6): 2156-2171

Oniam V, Taparhudee W, Yoonpundh R. 2018. Impact of different pond bottom soil substrates on Blue Swimming Crab (Portunus pelagicus) culture. Walailak J Sci and Tech 15 (4): 325-332.

Panithanarak T, Karuwancharoen R, Na-Nakorn U, Nguyen TTT. 2010. Population genetics of the spotted seahorse (Hippocampus kuda) in Thai waters: implications for conservation. Zool Stud 49 (4): 564 576.

Panithanarak T. 2017. Population genetic structure of marine organisms within the Gulf of Thailand. Burapha Science Journal 22 (3): 481499. [Thai]

Phinchongsakuldit J, Chaipakdee P, Collins JF, Jaroensutasinee M, Brookfield JFY. 2013. Population genetics of cobia (Rachycentron canadum) in the Gulf of Thailand and Andaman Sea: fisheries management implications. Aquacult Intl 21: 197-217.

Praipue P, Klinbunga S, Jarayabhand P. 2010. Genetic diversity of wild and domesticated stocks of Thai abalone, Haliotis asinina
(Haliotidae), analyzed by single-strand conformational polymorphism of AFLP-derived markers. Genet Mol Res 9 (2): 1136-1152.

Prakoon W, Tunkijjanukij S, Nguyen TTT, Na-Nakorn U. 2010. Spatial and temporal genetic variation of green mussel, Perna viridis in the Gulf of Thailand and implication for aquaculture. Mar Biotechnol 12: 506-515.

Rambaut A, Suchard MA, Xie D, Drummond AJ. 2014. Tracer v1.6. http: //beast.bio.ed.ac.uk/Tracer. (accessed on 23 June 2020).

Reed DH, Frankham R. 2003. Correlation between fitness and genetic diversity. Conserv Biol 17: 230-237.

Ren G, Miao G, Ma C, Lu J, Yang X, Ma H. 2018. Genetic structure and historical demography of the Blue Swimming Crab (Portunus pelagicus) from southeastern sea of China based on mitochondrial COI gene. Mitochondrial DNA A DNA Mapp Seq Anal 29: (2) 192198.

Rogers AR, Harpending H. 1992. Population growth makes waves in the distribution of pairwise genetic differences. Mol Biol Evol 9: 552569

Rozas J, Ferrer-Mata A, Sánchez-DelBarrio JC, Guirao-Rico S, Librado P, Ramos-Onsins SE, Sánchez-Gracia A. 2017. DnaSP 6: DNA sequence polymorphism analysis of large datasets. Mol Biol Evol 34: 3299-3302.

Russo CAM, Sole-cava AM, Thorpe JP. 1994. Population-structure and genetic-variation in two tropical sea-anemones (Cnidaria, Actinidae) with different reproductive strategies. Mar Biol 119: 267-276.

Saramul S. 2017. Seasonal monsoon variations in surface currents in the Gulf of Thailand revealed by high-frequency radar. Eng J 21 (4): DOI: 10.4186/ej.2017.21.4.25

Shan B, Hui M, Zhang X, Liu S, Cai S, Song N, Tu Z, Wang Y, Wang S, Gao T. 2018. Genetic effects of released swimming crab (Portunus trituberculatus) on wild populations inferred from mitochondrial control region sequences. Mitochondrial DNA A DNA Mapp Seq Anal 29 (6): 856-861.

Silva IC, Mesquita N, Paula J. 2010. Lack of population structure in the fiddler crab Uca annulipes along an East African latitudinal gradient: genetic and morphometric evidence. Mar Biol 157: 1113-1126.

Sodsuk PK, Praipanapong S, Sain-in N, Sodsuk S, Pewnain, P. 2012. Microsatellite-based analysis of genetic variation in hatchery populations of Asian seabass, Lates calcarifer (BLOCH, 1790). Thai J Genet 5 (2): 166-182. [Thai]

Sojisuporn P, Morimoto A, Yanagi T. 2010. Seasonal variation of sea surface current in the Gulf of Thailand. Coast Mar Sci 34 (1): 91-102.

Song N, Zhang XM, Sun XF, Yanagimoto T, Gao TX. 2010a. Population genetic structure and larval dispersal potential of spotted tail goby Synechogobius ommaturus in the north-west Pacific. J Fish Biol 77: 388-402.

Song N, Zhang XM, Gao TX. 2010b. Genetic diversity and population structure of spotted tail goby (Synechogobius ommaturus) based on AFLP analysis. Biochem Syst Ecol 38: 1089-1095.

Supmee V, Ngernsiri L, Sriboonlert A, Wonnapinij P, Sangthong P. 2012a. Population genetic analysis of violet vinegar crab (Episesarma versicolor) along the Andaman Sea coast of Thailand. Zool Stud 51 (7): 1040-1050.

Supmee V, Ngernsiri A, Swatdipong A, Wonnapinij P, Sangthong D, Sangthong P. 2012b. A single population of Thai vinegar crab (Episesarma mederi) living in the Gulf of Thailand. Proceeding of the $38^{\text {th }}$ Congress on Science and Technology of Thailand (STT38), Chiang Mai, 17-19 October 2012. [Thailand]

Supmee V, Sangthong P, Songrak A, Suppapan J. 2020. Population genetic structure of Asiatic Hard Clam (Meretrix meretrix) in Thailand based on Cytochrome Oxidase subunit I gene sequence. Bodiversitas 21 (6): 2702-2709.

Suppapan J, Pechsiri J, O-Thong S, Vanichanon A, Sangthong P, Supmee V. 2017. Population genetic analysis of Oceanic paddle crab (Varuna litterata) in Thailand. Sains Malaysiana 46 (12): 2251-2261.

Taguchi M, King JR, Wetklo M, Withler RE, Yokawa K. 2015. Population genetic structure and demographic history of Pacific blue sharks (Prionace glauca) inferred from mitochondrial DNA analysis. Mar Freshwater Res 66: 267-275.

Tajima F. 1989. Statistical method for testing the neutral mutation hypothesis by DNA polymorphism. Genetics 123: 585-595.

Untergasser A, Cutcutache I, Koressaar T, Ye J, Faircloth BC, Remm M, Rozen SG. 2012. Primer3-new capabilities and interfaces. Nucleic Acids Res 40 (15): e115.

Uthicke S, Benzie JAH. 2003. Gene flow and population history in high dispersal marine invertebrates: mitochondrial DNA analysis of 
Holothuria nobilis (Echinodermata: Holothuroidea) populations from Indo-Pacific. Mol Ecol 12: 2635-2648.

Wanna W, Rolland JL, Bonhomme F, Phongdara A. 2004. Population genetic structure of Penaeus merguiensis in Thailand based on nuclear DNA variation. J Exp Mar Biol Ecol 311 (1): 63-78.
Zainal KAY. 2013. Natural food and feeding and feeding of the commercial blue swimmer crab, Portunus pelagicus (Linnaeus, 1758) along the coastal waters of the Kingdom of Bahrain. J Assoc Arab Univ Basic Appl Sci 13: 1-7. 